\title{
Hours and Years in Employment Marital Adjustment among Women: Implications for Family Stability
}

\author{
Joyce Olufunke Ogunsanmi \\ Department of Guidance and Counselling, Faculty of Education \\ Ekiti State University, Nigeria
}

\begin{abstract}
The study investigated the influence of hours and years in employment on marital adjustment among married employed women in Ekiti state, South West Nigeria. The population of the study was all educated, married and employed women in the state. The sample consisted of 897 women, selected through stratified random sampling techniques from 10 local government areas. The instrument, a questionnaire tagged "Marital Adjustment Questionnaire" was designed and validated by the researcher. Two null hypotheses were postulated and tested at 0.05 level of significance. The data collected were analyzed using analysis of variance (ANOVA). Results of the analyses revealed that there was a significant difference in marital adjustment of the employed women with different number of hours per day. However, there was no significant difference in marital adjustment of the women based on the number of years spent in employment. Further analysis showed that in relation to hours in employment, there were significant differences in companionship and agreement on basic values of life. Also, there were no significant differences in affectionate intimacy and accommodation of the spouses based on hours spent in employment per day. Companionship had a significant result while affectionate intimacy, agreement on basic values or life and accommodation had no significant result based on the number of years in employment. The findings were discussed and recommendations made towards improvement of marital adjustment of married employed women.
\end{abstract}

\section{Introduction}

One of the most dramatic changes in the family over the past few decades in Nigeria has been the increase in employment of married women outside the home. With Western civilization in Nigeria and especially in the South West, changes have been observed in the educational, socio-economic and consequently in the marital life of the average Nigerian woman. More and more women now go out of their homes to take up employment

With the advent of Western education, men and women have been and are being trained in special occupations. As a result, the percentage of women in the Nigerian labour force continue to rise yearly [4].
The increases in the number of females who are employed outside their homes yearly at the local, state and federal levels in the civil service and general labour market, show that more and more females go out of their home to take up employment. As women leave the company of their husbands, contrary to what operated in the olden days, for employment outside their homes, casual observations show that there seems to be conflicts arising from the demands and expectations of marriage and employment. The process of marital relations, especially, affectionate intimacy between spouses has been affected by employment employed women who occupied dual roles due to employment and marriage had a lot of strains emotionally and psychologically [1], [2]. This invariably affected the degree of the affectionate intimacy between them and their husbands. Unlike in the past, wives nowadays go out of their homes for long hours. Hence, they are not in the company of their husband for long hours daily because of the fact that they are employed outside their homes. Taking up employment outside the home has created a lot of problems in marital relations [2], [7], [8].They exhibit various working arrangements in their marriage. The product of their interactions and/or compatibility of their individual traits vary. Thus, series of behaviours are used to cope with the demands of the marital relationship as they occur according to culturally assigned roles of being spouses. Consequently, with the level of educational development and employment opportunities in Nigeria, the institution of marriage is facing a lot of problems, including problems which arise from wife employment. Hence, the rate of divorce increases daily. Records of dissolution of marriage in the High Courts of Justice and Customary Courts of Nigeria in Ekitii State show a yearly increase in the total number of marriages that are dissolved. For instance, in 1993, 82 divorce petitions were granted in the Customary Courts of Nigeria at Ikere Ekiti, 49 in Ado Ekiti, 66 in Ijero Ekiti and 66 in Ikole Ekiti. The records revealed that $78 \%$ of the petitioners were women engaged in employment outside their homes. Such marriage partners had prayed the court for dissolution of their marriages or unions with durations ranging from 2 months to 30 years on the grounds of lack of love, lack of peace at home and companionship, lack of care for children and spouses and general maltreatment. Disagreement on basic 
values of life or matters important to life in the family forms a root cause of such marriage dissolution petitions. However, the causes of the breakdown of the marriage are not clearly understood and the reasons for the increase in the number almost on yearly basis are not clear enough. Some of the possible reasons might be connected with the fact that the women go out of their homes to take up employment and have been in it for many years. Considering the working for hours outside their homes fact that their husbands also went out of their homes to work, level of spousal companionship, accommodation, affectionate intimacy and agreement on basic values of life might have been greatly affected. His result of this might have been mal-adjustment emotionally and psychologically, although, a number of possible reasons for marital mal-adjustment have been assumed in Ekiti land. One of these reasons is contrary to the expectations that the wife develops positive attitude towards her husband on matters of sex relations, finance, accommodation and so on. She is expected to accommodate her husband on matters that are important to life in her marital relationship, since she is expected to be submissive.

Female spouse's employment has been considered in relation to marital adjustment. Findings have shown that wife's employment and entry into the Nigerian Labour force have some effects on marital relations [1], [5], [7]. However, the different levels and differences in marital adjustment of employed women in Ekiti state are not clearly understood. The magnitude of the influence of employment, especially, the number of hours and years on marital adjustment among women in Ekiti state is not clearly observable. Reasons for the observable conflicts between employment variables like hours and years in employment and marital adjustment are not understood beyond a few assumed causes commonly declared among them.

Possible reasons could be lack of adequate affectionate intimacy, companionship, accommodation and poor agreement on basic issues of life or consensus on matters that are important in life. Therefore, this study was an attempt to examine the differences in marital adjustment of employed women as influenced by the number of hours and years they have spend in employment outside the homes daily.

\section{Research Hypotheses}

1. There is no significant difference in marital adjustment of employed women based on different number of hours spent in employment per day.

2. There is no significant difference in marital adjustment of employed women based on the number of years spent in employment.

\section{Research Method}

The population consisted of all educated and employed married women in Ekiti state, Nigeria. The sample was a total of 897 employed women who were randomly selected from 10 local government areas through stratified random sampling techniques.

The instrument, a self-constructed questionnaire measured spouses, affectionate intimacy, companionship, accommodation and agreement on basic values of life among spouses.

It was adapted from Marital Adjustment Test (Locke, 1951) and labeled Marital Adjustment Questionnaire (MAQ).

Section A of the questionnaire solicited data on variables such as sex, age, hours spent in employment daily, total years spent in employment, educational qualifications and type of employment. Section B had 52 items designed to measure the degree of marital adjustment as experienced in relation to their employment. The item covered the following: spouse companionship (items 1-10), spouse affectionate intimacy (items 11-17), agreement on basic values of life (items 18-35) and accommodation of husband by wife (items 36-52). The questionnaire had a five point gradation response format which was to measure the degree of marital adjustment being experienced at as the time of data collection in the respondents' marriage.

The instrument was validated for face, content and construct validities. The construct validity coefficient of a pilot study was found to be 0.78 .

The reliability co-efficient of the instrument was found to be 0.85 and was significant at 0.05 level through a test -re test method. The instrument was administered on the subjects at their points of employment. The internal consistency of the instrument was determined through split-half method. The reliability co-efficient of 0.75 obtained was found to be significant at 0.05 level.

To test hypothesis 1 , the mean scores obtained by the women on the marital adjustment scale and scores on the number of hours in employment per day were analyzed using analysis of variance (ANOVA). Hypothesis 2 was also tested by the analysis of the mean scores obtained by the women on the marital adjustment scale with their scores on year of employment using Analysis of variance (ANOVA). 


\section{Results}

Table 1. Analysis of variance (ANOVA) of marital adjustment of married women with hours spent in employment per day

\begin{tabular}{|l|l|l|l|l|}
\hline Source of variation & $\begin{array}{l}\text { Sum of } \\
\text { squares }\end{array}$ & df & $\begin{array}{l}\text { Mean } \\
\text { squares }\end{array}$ & F \\
\hline Between groups & 8420.17 & 2 & 4210.09 & $4.33^{*}$ \\
\hline Within groups & 582790.24 & 600 & 971.32 & \\
\cline { 1 - 3 } TOTAL & $\mathbf{5 9 1 2 1 0 . 4 2}$ & $\mathbf{6 0 2}$ & & \\
& & &
\end{tabular}

NB * Significant at $\mathrm{P}<0.05$

There was a significant difference in marital adjustment among the women in relation to the hours spent in employment per day. Therefore, the hypothesis which states that there is no significant difference in marital adjustment among the women based on hours spent in employment per day was rejected.

Further analysis performed on the sub-variables of marital adjustment (companionship, affectionate intimacy, agreement on basic values of life and accommodation) with hours in employment per day by the women is as presented in Table 2 .

Table 2. Summary table of ANOVA on marital adjustment variables with hours in employment by married employed women

\begin{tabular}{|l|l|l|l|l|l|l|l|}
\hline $\begin{array}{l}\text { Source of } \\
\text { variation }\end{array}$ & SSbg & Df & MSbg & SSwg & Df & MSwg & F \\
\hline Companionship & 478.56 & 2 & 239.28 & 28430.23 & 600 & 47.38 & $5.05^{*}$ \\
\hline $\begin{array}{l}\text { Affectionate } \\
\text { intimacy }\end{array}$ & 150.33 & 2 & 75.26 & 18221.30 & 600 & 30.37 & 2.48 \\
\hline $\begin{array}{l}\text { Agreement on } \\
\text { basic values of } \\
\text { life }\end{array}$ & 1418.96 & 2 & 709.48 & 83296.80 & 600 & 138.83 & $5.11^{*}$ \\
\hline Accommodation & 495.10 & 2 & 247.55 & 86868.93 & 600 & 144.78 & 1.71 \\
\hline
\end{tabular}

Results revealed that there was a significant difference in companionship, no significant difference in affectionate intimacy, a significant difference in agreement on basic values of life and no significant difference in accommodation, all in relation to the number hours spent in employment outside the home per day.

Table 3. Analysis of variance (ANOVA) of marital adjustment with years $t$ in employment by married employed women

\begin{tabular}{|l|l|l|l|l|}
\hline Source of variation & $\begin{array}{l}\text { Sum of } \\
\text { squares }\end{array}$ & df & $\begin{array}{l}\text { Mean } \\
\text { squares }\end{array}$ & F \\
\hline Between groups & 3925.57 & 2 & 1962.78 & 1.94 \\
\hline Within groups & 809750.37 & 802 & 1009.66 & \\
\cline { 1 - 3 } TOTAL & 813675.94 & 804 & & \\
\hline
\end{tabular}

Table 3 revealed that there was no significant difference in marital adjustment among the women in relation to years spent in employment. Therefore, the null hypothesis which states that there is no significant difference in marital adjustment of employed women according to years spent in employment was accepted. Further analysis performed on the sub variables of marital adjustment (companionship, affectionate intimacy, agreement on basic values of life and accommodation) with different years in employment is presented in Table 4.

Table 4. Summary table of ANOVA on marital adjustment sub-variables with years in employment by married employed women

\begin{tabular}{|l|l|l|l|l|l|l|l|}
\hline $\begin{array}{l}\text { Source of } \\
\text { variation }\end{array}$ & SSbg & Df & MSbg & SSwg & Df & MSwg & F \\
\hline Companionship & 605.08 & 2 & 304.04 & 42187.12 & 802 & 53.60 & $5.78^{*}$ \\
\hline $\begin{array}{l}\text { Affectionate } \\
\text { intimacy }\end{array}$ & 153.39 & 2 & 76.69 & 28345.86 & 802 & 35.34 & 2.17 \\
\hline $\begin{array}{l}\text { Agreement on } \\
\text { basic values } \\
\text { of life }\end{array}$ & 161.88 & 2 & 80.94 & 115172.66 & 802 & 143.61 & 0.56 \\
\hline Accommodation & 231.96 & 2 & 115.98 & 115868.37 & 802 & 144.47 & 0.80 \\
\hline
\end{tabular}

The result revealed a significant difference in companionship, and no significant differences in affectionate intimacy, agreement on basic values of life and accommodation in relation to years in employment among the women.

\section{Discussion}

The finding revealed that the number of hours spent in employment per day significantly influenced marital adjustment among the subjects. Contrary to this finding is the finding of Nathawat and Mathur that revealed that working women had better marital adjustment and subjective well-being among IndianEducated working women than housewives [6]. Also, Thind and Jaswal had similar findings that wives employed outside the home for hours were significantly more socially adjusting with their husbands than wives unemployed [10]. Similar to the findings of this study is the finding of EbenuwaOkoh that revealed involvement in work/employment as a significant correlate of marital adjustment among married persons in Delta state, Nigeria [3].

The probable explanation for the finding in Ekiti state could be the fact that the women who were involved in various employment statuses of being teachers, nurses, bankers and so on who worked shifting, non-shifting, long hours and irregular hours at work had been influenced in companionship, affectionate intimacy and accommodation in relation to their husbands. 
This study revealed no significant difference in marital adjustment among the subjects who had spent different number of years on employment. Thus, number of years in employment did not lead to a difference in marital adjustment. It appears the Ekiti women had positive attitude towards work or employment. They seemed to have carried over the traditional sense of duty to employment in the modern day. Their belief that works is a means to an end seemed to have affected their marital relations as employed women. So, employment, generally, and years in employment had no significant influence on their marital adjustment.

The result from the further analysis that indicated a significant difference in companionship among the women could be explained with the fact that young women who were probably new in employment would miss their husbands as they go out of the home to work.

\section{Conclusion and counselling implications of the findings}

The following conclusion could be drawn from the analyses of data and the interpretation of the results: Hours in employment per day is a significant variable in making a difference in marital adjustment among married employed women. Also, it could lead to difference in companionship and agreement on basic values of life but does not make any difference in affectionate intimacy and accommodation.

The variables of interest of this study concerning employment of married women outside their homes should be emphasized by guidance counsellors and marriage counsellors while providing pre-marital and marital counselling to intending and married couples. Hopefully, this will forestall adjustment problems in their marriage as they perform their dual roles as wives and women employed outside their homes.

The results of this study have implications for great emphasis on agreement or basic values of life and accommodation of each other by spouses because these would naturally make room for companionship and affectionate intimacy between them.

Generally, the results have implications for premarriage counselling, marriage counselling programmes, personnel / marriage counselling, marriage enrichment programmes and counsellortraining programmes.

\section{References}

[1] Adegoke, A. (1987) female labour participation and marriage Happiness. A study of selected married women in Ilorin and Ibadan. The Nigerian Journal of Guidance and Counselling, 3 (1 \& 2), $132-140$.
[2] Ala, M.O. (2010). Marital instability among couples in Ado Local government area of Ekiti state. Unpublished B.Ed thesis, University of Ado Ekiti, Nigeria.

[3] Ebenuwa-Okoh, E.E. (2008). Personality variables as correlates of marital adjustment among married persons in Delta State of Nigeria. Educational Research and Review, 3 (8) 275-279.

[4] Federal Office of Statistics, (1998, 2004, 2011). Annual Abstract of Statistic. Lagos.

[5] Hassan, T., Sotonade, O.A.T., (1993). Age at marriage, spouse age differential and relative occupational status as determinants of marital adjustment. Journal of Research on counselling psychology, 3 (1), 66-74.

[6] Nathawat, S.S., Mathur, A., (1993). Marital adjustment and subjective well-being in Indian Educated Housewives and working women. The Journal of Psychology: Interdisciplinary $\square$ Applied, 127 (3), $353-$ 358.

[7] Ogunsanmi, J.O., (2001). Employment and Marital Adjustment among married women in Ekiti state. An unpublished Ph.D. thesis, University of Ado Ekiti, Nigeria.

[8] Owuamanam, T.O. (2008). The woman academic and her home. An unpublished paper presented at the seminar organized by the National Association of Women in Academics (NAWACS), University of Ado Ekiti.

[9] Sears, H.A., Galambos, N.L., (1992). Women's work conditions and marital adjustment in Two-Earner Couples: A structural model. Journal of Marriage and Family, 54 (4), 789 - 797.

[10] Singh, R, Thind, S.K., Jaswal, S. (2006). Assessment of marital adjustment among couples with respect to women's educational level and employment status. The Anthropologist, 8 (40), 259 - 266. 